Seweryn CICHON

\title{
2.8. MANAGING THE WORK OF UNIVERSITY TEACHERS WITH MODERN EDUCATIONAL TOOLS
}

\section{Summary}

The use of a broad spectrum of modern teaching aids offers great opportunities and simplifies the teaching process. The choice of modern educational aids depends not only on teachers but also increasingly from the students. Academic teacher, as an attentive observer, should notice which modern teaching aids are interesting to the beneficiaries of educational services, and the most often use the chosen ones. It makes teaching more attractive and the assimilation of knowledge easier. In the article was discussed the essence of teaching aids in the process of management of teachers and students work, also were characterized modern teaching aids and applying them. It also described the role played by information technology in higher education, particularly the use of interactive educational platform as a form of education.

Keywords: university management, information technology in management, modern educational aids, the work of university teachers, the teaching process

\section{Introduction}

Denek presents the following types of competence of academic teachers (Denek, 2000): praxiological competence, expressing itself with effectiveness of teacher management (i.e. planning, organizing, controlling and evaluating educational processes);

- Communication skills, express themselves in effectiveness of language behaviours in educational structures by the teacher;

- competence of the cooperation - the effectiveness of prosocial behaviours and the efficiency of teacher's integration actions;

- $\quad$ creative competence, innovativeness and the non-standard measures;

- $\quad$ informatics competence, i.e. efficient using modern sources of information.

Academic teacher has to be more than just a person transmitting knowledge, information, currently the teacher has to stimulate the creativity of the student and the curiosity in acquiring knowledge, also teacher has to take care of emotional health of students and cause them to become active participants in the life of civil society, successfully combining theory and practice (Day, 2008, p. 27). The university teacher has the task of fulfilling a few basic responsibilities and functions: education, upbringing, welfare, environmental, enforcement and evaluation achievements and organizational skills, both in the organization of their own work and work of their students (Banach, 2009, p. 7). 


\section{The essence of teaching aids in the management of teacher and student work}

In the encyclopaedic perspective, teaching aids are being called the aids education aids. These include all kinds of items, which affect the senses of students. The use of teaching aids facilitates the analysis of reality, shortening and diversify the teaching process and evoking such insights that will help in a shorter time pass more information (www.encyklopedia.pwn.pl). Cz. Kupisiewicz claims, that "objects that deliver to students specific sensory stimuli, affect their eyesight, hearing, touch, etc., facilitate their direct and indirect recognition of the reality (Bereźnicki, 2007, p. 369)". According to J. Półturzycki as teaching aids can be considered "both tangible objects that provide specific sensory stimuli, as well as technical devices that facilitate the transmission of stimuli, and which are used by an academic teacher and students (Półturzycki, 2004, p. 13)". The importance of teaching aids refers to the organization of the process of teaching and learning. It can guarantee the best equipment in the competencies that are needed at each stage of education. This organization is closely associated with using the wide range of the help, which functions consist among others on (www.podn.wodzislaw.pl):

- $\quad$ Facilitating the thought processes;

- $\quad$ Extending the range of learner contact with reality and motivation;

- A tool for learning (e.g. cards with tasks for groups).

Recalled teaching measures serve as a media, which means that they are subordinated objectives contents, and they must be adapted to the situation of learning and educational needs of students.

Teaching aids mainly (www.efs.men.gov.pl):

- have an informative function, so that learners are able to better and more effectively remember;

- $\quad$ are a fundamental source of knowledge and skills;

- $\quad$ are a tool helping to synthesize knowledge;

- $\quad$ are a tool facilitating analysing technical occurrences;

- $\quad$ are a diagnostic tool that verifies knowledge.

Teaching Aids enrich and enhance the learning process, but also help academic teachers organize teaching process, fulfilling a lot of important functions, such as (Moos, 1996):

- function of introducing into the teaching process;

- function of the basic source of knowledge;

- function of analysing technical processes;

- function of strengthening;

- function of verifying hypotheses for solving problems;

- function of controlling.

In the literature can find many classifications of teaching aids. Teaching aids are divided depending on what senses are involved in the learning process and learning. R. Więckowski divided teaching aids on (Więckowski, 1998, p. 121-122):

- visual, e.g. slides, computer programs, schemes, symbols, diagrams, models, tools, preparations; 
- aural, e.g. audio recordings along with devices enabling to use them, musical instruments, etc.;

- visually - aural, e.g. films.

There is also a division of teaching aids according to the criterion of their complexity, by this classification distinguishes (www.edukator.org.pl):

- $\quad$ straight aids, e.g. models, graphs, maps, images;

- complex aids, of e.g. mechanical, electrical, electronic equipment (computers, projectors, transparencies, etc.).

To modern teaching aids, which university teachers can use in the management of their and the students' work, include (PHU GERD-Madex Sp. J., p.1-83) projectors; screens; interactive, copying, dry-removable, information boards; tablets; tests systems; visualizes; slide projectors; equipment for the videoconference; flipcharts; and planners.

Projectors, especially those with focal lengths, are beginning to displace conventional devices from the market, through the fact that projectors do not shine into the eyes of teachers, protecting their eyes perfectly are suitable for using together with the interactive board. Today, modern projectors have a high resolution and high brightness. Screens for displaying multimedia presentations can take different forms, i.e. electrically or manually pull-down screens, floor screens, on the tripod, are comfortable to use and can have different shapes. To conduct classes using interactive board is enough that academic teacher will use a finger or an ordinary pen, board surface is magnetic, dry-wipe, resistant to damage and this teaching aid can function with wireless tablets, systems to tests, visualizes, speakers. The modern software to interactive boards enables among others:

- control the computer using the interactive board;

- $\quad$ storing material formed on the board during classes in such formats as: an image file, web page or PDF document;

- $\quad$ change the language of software;

- recognizing the handwriting.

Applying systems to tests by academic teachers during classes has only advantages:

- instant check the level of mastering material - interactive tests of the knowledge;

- $\quad$ quick and objective assessment of results of the teaching;

- $\quad$ conducting surveys, the opinion poll;

- $\quad$ game shows, quizzes, interactive games, etc.;

- $\quad$ saving time during classes - immediate and opposite reaction;

- $\quad$ saving of the work of the university teacher;

- $\quad$ saving of paper.

The role of visualization is to enable display any objects or documents enlarged using the projector or TV sets.

Examples of applications this teaching aid are:

- General issues on all subjects, showing on the screen: books, homework of students, 3D objects (e.g. globe, a variety of teaching accessories, tissue samples);

- Live-recording classes, experiments, operations, techniques can be recorded and played back in later time;

- $\quad$ Medical schools, showing X-ray images, 3D objects (e.g. bones, tissue samples); 
- Law and Administration, the presentation of evidence and documentation, comparing documents and objects on the "one to one" principle presentation of maps, diagrams, plans;

- e-learning, transmission of images live through the Internet (to participants in the videoconference) including viewing prototypes, samples, training materials and documents.

The most commonly used, by academic teachers, aids include overhead projectors which are divided into stationary and portable.

Applying copying boards by academic staff brings many benefits:

- $\quad$ ideal for use during scientific meetings or classes at higher language schools;

- $\quad$ effective use of working time;

- larger workspace - two scrollable panels for taking notes;

- possibility of return to the notes on the previous page;

- possibility of handing out notes from classes without the need to copy them by students;

- $\quad$ no more problems with spending on paper and used blocks to flipchart.

The electronic copying flipchart used on the market of university education services is used because of:

- The effective use of working time, students focus on the discussed issue instead of preparing notes;

- Two scrollable panels for taking notes, no unnecessary waste in the form of written sheets of paper;

- the ability to send meeting notes by e-mail, without necessity of their rewrite by the participants;

- ability to restore a complete history of notes from classes, each of participants receives the same version of notes;

- $\quad$ economical and comfortable use;

- complete data protection, notes can be wiped off without the risk that access to them will have e.g. students from another dean's group.

Wide choice of planners with the different time scope, from a week to an entire year is a universal solution- now it is possible to describe every column and row depending on needs. Planners have an extremely lightweight and durable construction.

\section{Information Technology in Higher Education}

The term "information society" refers to the four meanings (Haber, 2010, p. 55):

1. Evolutionary - refers to the successive stages of social and economic development. The first step is the development of agriculture, the second - the industry, and the third is the development of knowledge and information.

2. Ideological - refers to the public policy long-term objectives which focus on social and economic transformations. Change the economic system gives a chance for development

3. Technology - indicates the rapid development of IT technology, which transforms systems of work, employment, governance, management methods and education, and introduces new cultural and civilization models. 
4. Cognitive - refers to the development of sociological theories related the search for the essence, genesis and meaning of the formation of information society.

The great importance and the scope of the notion "information technology", which includes such terms and areas as computer science, information, telecommunications, media, multimedia, forces to clarify mentioned earlier definition through the recognition of information technology including its scope conceptual elements (Osmańska-Furmanek, 1999, p. 18):

- creating, using and the influence of media messengers, including multimedia, on social communication through information media;

- synthesis and analysis of the information;

- ethical, social, legal aspects and education human actions in the sphere of the information technology;

- confidentiality and data security.

The basic skills and issues of information technology that each university teacher should get, include (Sysło, 2007, p. 49):

- basics of using information technology, its tools and methods of use;

- the role and possible ways of using the information technology on the classes conducted by the teacher;

- the use of information technology as part of own workshop;

- social, ethical and legal aspects in the access and using the information technology;

- the use of information technology as a teaching aid during classes.

The process of teaching at the university based on elements of modern didactics, mass production of information, in all subjects, should lead to increase knowledge and qualifications of academic teachers, proportionally to the development of technique and information technology (Mianecka, 2010, p. 9).

Thanks to classes taking into account the information technology students have the chance to get (Sysło, 2007, p. 31):

- ability of correct using sources of information and tools for its processing;

- knowledge about possible applications of this technology, including the sources from which it is possible to obtain information and the tools e.g.: spreadsheets, databases, software for simulation and modelling and communicating via a computer network;

- knowledge about the new opportunities that information technology provides, the consequences of its activities, capabilities and restrictions.

It is noted that information technology plays a very important role in teaching, which cannot be compared with the role of other technologies. The man is a creative and independent being, so science should not only make possible to process information, but also enable the creation of new cognitive structures based on acquired information, development of skills the constant learning and the ability to cope with new information resources (Sysło, 2004, p. 23). 


\section{The educational platform as an advanced teaching system}

E-learning is a modern, interactive form of education more and more often appreciated by higher education institutions, as well as individual persons, its use it is possible thanks to applying the teaching aid which is e.g. computer. Functioning in the information society, knowledge society, requires constant improving from university teachers and students - of learning through the entire life - lifelong learning. Applying the latest information technology supports the preparation of attractive educational materials, thus affecting motivation to learn and effectiveness the effectiveness of passing the exams. It does not require that rent classrooms or the physical presence of teachers. E-learning is supporting the acquiring the ability to use different sources of information published on the Internet and the use of tools to facilitate communication, both interpersonal and between groups of people (networked communities: academic teacher - student, student - student) (Juszczyk, 2002, p. 241).

From the point of view of the genesis of e-learning it should refer to the so-called distance learning models, among which are distinguished (Nowoczesne metody nauczania..., p. 11):

- correspondence model: books, scripts and other printed materials;

- multimedia model: audio/video cassettes, educational programs, interactive tapes;

- synchronous model: video conferencing, audio conferencing, television and radio broadcasts;

- asynchronous model: interactive online multimedia, education via computer and the Internet, Internet sources;

- intelligent asynchronous model: communication via computer uses automatic response systems, virtual campuses with access to resources.

The e-learning module has the following functions:

Information:

- organizational;

- education;

- complementary;

- integrative;

- verifying (www.zawodowcy.org/c/wiadomosci)

The advantages of using e - learning in higher education are (www.eip.pl):

- relatively durability of knowledge through a scheduled cycle of interaction and summary tests: holding the attention of students at a high level depends on the amount of interactivity amounts of interactive elements used in during the lesson;

- course materials available on the educational platform even after the lessons allow to maintain the sustainability of knowledge, its circulation and the ability to return;

- possibility of quickly and easily create e-tests along with current verifying own knowledge.

In case of e - learning, students work without physical, direct contact with the university teacher and classmates, therefore they have to be more engaged and motivated to learning (Koprowska, 2007, p. 30-39). 


\section{Conclusions}

Significant changes in computer science and progressive technology are forcing changes in management of higher education, the significant transformations, which are extremely important element in the information society. Priority tasks of universities include preparing students for living in the information society, whose functioning is hard to imagine without information technology and the ability to use it (Siemieniecki, 1998, p. 59). Education, similarly to other spheres of modern man life, should undergo transformations due to changes in social and technological conditions. The principal task of education is to help a young person in achievement of competencies or ability to use modern technology (Sysło, 2004, p. 12). Due to the different areas of appearing, in the literature occurs several types of distance learning. One of them is e-learning. Priority objective of this system is the online support for educational activities in high school. It operates based on educational platform, what facilitates communication on the line: academic teacher - student, student - student (Penkowska, 2009, p. 139).

\section{References}

1. Banach Cz. (2009): Teacher of our expectations and needs from A to Z, Wydawnictwo Wyższej Szkoły Ekonomii i Innowacji, Lublin.

2. Bereźnicki F. (2007): Didactics of the general education. Wydawnictwo Impuls, Kraków.

3. Day Ch. (2008): The teacher with a passion. How to keep the enthusiasm and commitment to work, Wydawnictwo GWP, Gdańsk.

4. Denek K. (2000): Vocational training of teachers in the context of the reform of the education [In:] Jasiński Z., Lewowicki T. (eds.) Pedeutology problems at the turn of the $X X$ and XXI century Wydawnictwo Uniwersytetu Opolskiego, Opole.

5. Juszczyk S. (2002): Distance Education: codification of the concepts, rules and processes, Toruń: Adam Marszałek.

6. Catalog of Presentation Products, PHU GERD - Madex Sp. J.

7. Koprowska D. (2007): The IT education and the e-learning in managing of the microenterprise, Constant education of Adults, 3.

8. Mianecka J. (2010): The competence of teachers in the field of information technology and their attitudes toward this technology and its use in the pedagogical process - conclusions from research., [in:] Lewowiecki T., Sienieniecki B. (eds.), Language - communication media - education., Wydawnictwo Adam Marszałek, Torun.

9. Moos J. (1996): Technical High School. Program and organizational assumptions. Wydawnictwo Instytutu Technologii Eksploatacji, Radom.

10. Modern teaching methods - analysis of elaboration within the project (2011): „Profiling of unemployed as an instrument of extending the occupational activity of groups requiring the specific support", Torun.

11. Osmańska - Furmanek W. (1999): New information technologies in the education. Lubuskie Towarzystwo Naukowe, Zielona Góra.

12. Penkowska G. (2009): Computers in education - from the object to the method of training. Wydawnictwo Uniwersytetu Gdańskiego, Gdańsk.

13. Pólturzycki J. (2004): Didactics for teachers. Wydawnictwo Adam Marszałek, Toruń. 
Cichoń, S.

14. Siemieniecki B. (1998): Needs of transformations in the education for the development of the thinking., [in:] Rubacha K. (ed.), Around the school and education. Synthesis and reflections, Wydawnictwo Adam Marszałek, Torun.

15. Sysło M. (2007): Methodology of the IT education: solving problems, algorithmics, programming [in:] Mossa J. (ed.) Education for the development of the information society, Łódzkie Centrum Doskonalenia Nauczycieli i Kształcenia Praktycznego, Łódź.

16. Sysło M. (2004): Information Technology in Education., Instytut Informatyki Uniwersytetu Wrocławskiego, Wrocław.

17. Więckowski R. (1998): Early-school pedagogy, Wydawnictwo WSiP, Warszawa

18. www.edukator.org.pl [20.04.2015]

19. www.efs.men.gov.pl [24.04.2015]

20. www.eip.pl [02.04.2015]

21. www.encyklopedia.pwn.pl [12.04.2015]

22. www.podn.wodzislaw.pl [12.04.2015]

23. www.zawodowcy.org/c/wiadomosci [30.03.2015] 